\title{
WNT1 Gene
}

National Cancer Institute

\section{Source}

National Cancer Institute. WNT1 Gene. NCI Thesaurus. Code C18355.

This gene plays a role in signal transduction and intercellular communication. It is involved in neural development. 